\title{
The Scrutiny of Brexit in National Parliaments: Germany, Luxembourg and the Czech Republic Compared
}

Vanessa Buth (University of East Anglia), Anna-Lena Högenauer (University of Luxembourg) and Petr Kaniok (Masaryk University)

\section{The final chapter was published as:}

Buth V., Högenauer AL., Kaniok P. (2019) The Scrutiny of Brexit in National Parliaments: Germany, Luxembourg and the Czech Republic Compared. In: Christiansen T., Fromage D. (eds) Brexit and Democracy. European Administrative Governance. Palgrave Macmillan, Cham

\begin{abstract}
The outcome of the Brexit referendum has led to a highly mediatized battle of power between the British government and parliament over how much influence the latter can exert over the British position in the negotiations with the European Union. At the same time, the role of parliaments in the remaining member states has received virtually no public attention, despite the fact that the stakes are also high for their publics. The aim of our paper is to shed light on dynamics of parliamentary control of Brexit in the remaining member states through a comparative study of the German, Czech and Luxembourgish parliaments. Each of these member states has one or several key interests at stake in the negotiations, such as exports, the financial sector and future contributions to the EU budget (Germany, Luxembourg), or migration to the UK and the maintenance of EU policies and their budgetary health (Czech Republic). The three cases represent geographical diversity and differently sized countries, to take into account different levels of governmental-influence over the Brexit negotiations. The study will focus on the formal powers of parliaments, their actual mobilization and the key dynamics that mark their scrutiny of the Brexit negotiations.
\end{abstract}




\section{Introduction}

The outcome of the British referendum on the UK membership of the European Union raised more challenges than expected. Governments quickly realized that they not only had to renegotiate the relationship between the UK and the EU across a wide-range of policies, but that they were also facing questions in terms of process. One question that almost immediately emerged on both sides of the tables was about parliaments: To what extent should the national parliaments and the European Parliament be informed about the negotiations? Should they be consulted, and if so at regular intervals or mostly at the end of the process? Should they be able to approve or reject the outcome?

In the case of the European Parliament, its formal powers are defined by Art. 50 TEU: it must give its consent to the final agreement for the agreement to take effect. The European Parliament used this formal power to clarify at an early stage of the negotiations that it did not intend to simply vote once at the end of the negotiations, but that it also expected to be regularly briefed and consulted during the negotiations.

The case of national parliaments is less clear, as Art. 50 TEU makes no reference to them: The EU Treaties usually do not interfere in what are considered domestic power structures. In the case of Britain, this ambiguity resulted in a public argument about the role of parliament both in triggering Brexit and in approving the final settlement. Originally, the British government intended to minimize the role of parliament in Brexit - a stance that clashed with a claim of the Brexit campaign to defend parliamentary sovereignty. In practice, the argument resulted in a high-profile court case and repeated stand-offs between parliament and government that are ongoing at the time of writing (February 2018) and that attracted the attention of both the media and academics (e.g. Gee and Young 2016; Phillipson 2016; Eleftheriadis 2017; Mabbett 2017; Poole 2017).

By contrast, the question of the rights of the parliaments of the EU-27 has attracted little public or scholarly attention. Is this indicative of a lack of interest on the part of the parliaments? Do they accept that the Brexit negotiations are the prerogative of governments or do they feel that the impact of Brexit will be too small/unpredictable to merit attention? These doubts can be quickly dismissed. According to the $27^{\text {th }}$ COSAC report (COSAC 2017) 35 out of 37 parliaments and parliamentary chambers that took part in its survey want their governments to regularly inform them about the Brexit negotiations. 28 out of 38 parliaments or chambers would like to have the opportunity to ask questions from the negotiating team and discuss the progress of negotiations. Finally, 21 out of 38 parliaments think that the European Commission and national parliaments should come together on a regular basis to discuss the negotiations. Despite the absence of a public debate on the powers of parliaments, national parliaments in the EU-27 are thus clearly interested in Brexit scrutiny. 
The aim of this chapter is to analyse national parliaments along the four dimensions outlined in the introductory chapter of this volume. The constitutional dimension covers the formal powers of national parliaments and we are looking in particular at the dynamics of the executive-legislative relationship as well as the role of bicameralism. Regarding the procedural dimension, we analyse how national parliaments make use of these procedures in practice, whether they attempt to modify existing procedures and to what extent they make use of interparliamentary channels. The partypolitical dimension analyses to what extent parliamentary debates are shaped by differences between governing and opposition parties in Brexit scrutiny, including Eurosceptic parties, and to what extent the 'national interest' acts as a unifying factor or determines the precise issues that receive attention. For these purposes, the paper compares three cases - Germany, the Czech Republic and Luxembourg. The paper is based on qualitative interviews and document analysis from 2013-2017, encompassing the period before the Brexit referendum and the first phase of the Brexit negotiations.

\section{State of the art}

The case of Brexit is unique. No member state has ever left the EU, and there are thus no historical examples of how parliaments could, would or should be involved in this process. However, Brexit happens in the context of an evolution of national parliamentary involvement in EU policy-making that spans decades, and it thus can be placed in this literature.

Firstly, the Brexit negotiations are an executive-dominated process - especially as far as the EU-27 are concerned. Before the Brexit referendum, the negotiation of a special deal for Britain, should it choose to remain, was dominated by the member state governments and the European Commission, with no formal involvement of national parliaments. Since the referendum, the EU negotiation team responds primarily to a mandate from the European Council and to potential pressures from the EP. The role of national parliaments in this is again not spelled out. As art. 50 TEU does not mention national parliaments, the final decisions on Brexit could probably be taken without national parliamentary involvement - unless national parliaments insist that their government consults them before the final vote. This situation is reminiscent of the literature on national parliaments in the EU pre-2005, which argued largely that Europeanization was synonymous with an increase in executive dominance and a weakening of national parliaments: As competences moved to the European level, governments turned into legislators in the Council of Ministers, and national parliaments struggled to control them due to a mix of a lack of formal powers, an information deficit and disinterest. Very few parliaments such as the Nordic parliaments, managed to set up effective scrutiny systems (cf. Norton 1996; Maurer and Wessels 2001; O'Brennan and Raunio 2007). 
However, the situation of national parliaments has substantially improved since the early $2000 \mathrm{~s}$. As national parliaments became aware of their loss of powers, they started to fight back by demanding more formal powers (e.g. better control powers over the government), by setting up specialized EU affairs committees to conduct the scrutiny and by demanding reform on the European level (e.g. Dimitrakopoulos, 2001; Bergman et al. 2003; Auel, 2005). Winzen thus argues that the strength of national parliaments in EU policy-making overall increased from 2000 to 2010 (Winzen, 2012, 663-5). Winzen noted that the member states that joined after 2004 did indeed tend to give their national parliaments more formal powers of scrutiny.

The recognition of national parliaments in the Treaty of Lisbon and the introduction of the Early Warning System, that gives national parliaments an opportunity to object to new European legislation, if it violates the principle of subsidiarity, marks a new step in the strengthening of national parliaments. While the Early Warning System concerns only EU legislation (and does not cover the Brexit negotiations), it did motivate many national parliaments to further improve their scrutiny procedures, encourage sectoral committees to comment on EU affairs falling into their areas of expertise, and liaise more actively with other European Parliaments in COSAC (e.g. Auel and Christiansen 2015; Gattermann et al. 2016). Högenauer and Neuhold also show that many national parliaments increased the number of EU experts at their disposal after the Treaty of Lisbon and gave them an important supporting role in scrutiny (Högenauer and Neuhold 2015; Högenauer et al. 2016). The Eurozone and immigration crises led to a further mobilization of national parliaments, as they highlighted the potential salience of EU affairs for voters. Auel and Höing (2015) show that the parliaments of countries that were particularly affected by the Eurozone crisis are more likely to scrutinize EU affairs actively, thus showing that scrutiny can be driven by national salience and key events. In addition, national parliaments with strong formal powers are more likely to be active scrutinizers. Finally, national parliaments recently started to assert their influence in the course of major international trade negotiations, such as the trade agreements with Canada and the United States. They are thus better prepared for the complicated process of the Brexit negotiations than they would have been 15 or 20 years ago.

Based on the literature on parliamentary scrutiny of EU affairs more generally, we thus have a number of expectations as regards national parliaments and Brexit. Firstly, we expect institutional strength (i.e. formal powers) to have a positive impact on levels of scrutiny. In addition, we would expect the size of the country to matter, as the governments of large countries are more likely to be able to shape the outcome of the negotiations (and to shape them across a range of areas) compared to the governments of small countries. As the governments of small countries will find it difficult to defend even a small number of key interests, we expect their parliaments to be more supportive of the governments and also rally around key national interests. Existing research also suggests that there 
are differences in activity between upper and lower houses and between unicameral and bicameral systems. Unicameral parliaments, according Auel, Rozenberg and Tacea, "are clearly the most active when it comes to issuing mandates or resolutions, but they debate EU affairs far less often in the plenary than chambers in bicameral parliaments" (Auel, Rozenberg and Tacea 2015:75). Thus, we expect the parliaments to follow a similar path in case of Brexit - the Luxembourgish parliament focusing on resolutions, whereas the Czech and German chambers will make active use of debates. Finally, just as parliamentary scrutiny of the eurozone crisis depended on national salience, we also expect the scrutiny of Brexit to focus on issues salient for the member state in question and to be driven by key events. In other words, we expect different parliaments to talk about different types of issues. Regarding the party politics dimension, we expect to find differences between opposition and government as well as between Eurosceptics and pro EU parties.

To test these expectations, we have chosen three countries (Germany, the Czech Republic and Luxembourg) that correspond to a large, a medium-sized and a small member state and that include two bicameral parliaments and one unicameral parliament. The German parliament has the most extensive formal powers (ranked joint $6^{\text {th }}$ in the EU by Winzen 2012 with a score of 2.17), compared to the Czech Parliament (1.83) and the Luxembourgish parliament (0.67). More recently, Auel, Rozenberg and Tacea (2015) produced similar results on institutional strength. In their overview, both German chambers belong among the strongest EU chambers ( 0.78 for Bundestag ranking 2nd and 0.62 for Bundesrat ranking 8 th) followed by closely by the Czech chambers ( 0.59 for Senate ranking 10 th, 0.58 for Chamber of Deputies ranking 11th). On the contrary, Luxembourg can be found towards the bottom of the chart (0.40) (Auel, Rozenberg, Tacea 2015). The same authors also measured EU national parliaments' activity score in EU affairs. Here the picture looks different. The Bundestag moves down to rank 5 (0.34), followed by the Czech Senate $(0.33$, rank 6$)$, which now surpassed the Bundesrat $(0.24$ rank 13). The Luxembourgian parliament moved up towards the lower middle (0.16), swopping places with the Czech lower house now towards the bottom rank (0.10).

In our case selection, we moreover tried to combine a good balance of a set of criteria beyond institutional powers. The theory suggests that the salience of an issue and national interests impact the parliamentary scrutiny activity. We have therefore selected countries that are all differently affected by Brexit and which are expected to play a different role in the whole process. Germany represents a member state that is expected to be heard much during the negotiations. Specific concerns for Germany is the financial contribution to the EU budget as well as its benefit from the latter, as well as its trade sector and citizen mobility. In the Czech Republic Brexit is perceived as a salient issue, but the number of concerns is limited to several key areas - particularly citizens' rights 
and budgetary health. Luxembourg represents a case where the salience of Brexit is high in a key economic sector - the financial sector.

\section{Constitutional dimension}

The formal powers of the three case studies of parliaments in EU affairs differ along two lines whether the powers are centred around information-gathering or government control, and whether only the EAC is responsible for EU affairs or whether all affected committees are.

The Luxembourgish parliament is the weakest parliament of the three in EU affairs: The Constitution is silent on the role of parliament in EU affairs. Instead, parliament defines the scrutiny procedures autonomously in its rules of procedure (RoP) (Spreitzer 2014). Most of the rules are contained in an Aide-Mémoire on the cooperation between the Chamber and the Government included in Annex 2 of the RoP. It is worth noting that the Committee on Foreign and European Affairs shares the responsibility over EU affairs with the sectoral committees, which are expected to issue opinions on matters falling into their area of expertise.

According to the Aide-Mémoire, the parliament has the right to receive a wide range of EU documents, to be informed by the government orally or in writing about topics that are salient for Luxembourg. In addition, the sectoral committees can invite members of the government to answer questions before and after Council or European Council meetings. However, it has no mandating powers, and while the government should transmit information in time to allow the Chambre to define its own position and send it to the government, the government is not obliged to follow that position. In addition, the government will present an annual report on EU politics. In practice, the report is usually presented by the Foreign minister and followed by a public debate. The report on EU politics is of relevance in this context, as it allowed for extensive debates on Brexit and the Future of the EU more generally. Finally, the government has to inform the Chambre about accession negotiations when a new state wishes to join the EU, set out its own position and consult parliament. Technically these rules do not mention states leaving the Union, but one can assume that the Chamber will expect them to apply to Brexit.

By contrast, the chambers of the Czech parliament are far more powerful. Regarding the institutional set-up of the Czech European policy, both chambers are in a similar position and have similar tasks. Both the Chamber of Deputies and the Senate have their own EU affairs committee (EAC). They are the most important actors shaping the chambers' EU policies as plenaries very rarely change or reject motions for resolution proposed by the EACs (Hrabálek, Strelkov 2015: 496). The EACs of both chambers share similar tasks. They focus on subsidiarity checks of EU legislation proposals, assessing EU legislation and scrutinizing governmental EU policy. Further details are in cases of both chambers 
specified in their respective rules of procedures. There is no formal document defining mutual relations between both chambers in the EU affairs.

Regarding Brexit, no changes to the internal procedures or relations between chambers and government have been adopted. Only the lower house's EAC is considering the possibility to establish a specialized Brexit subcommittee or a specific working group. This possibility was discussed in the beginning of January 2018 (Interview with Ondřej Benešík, Chair of the Committe for EU Affairs, Chamber of Deputies of the Parliament of the Czech Republic, 16/1/2018.). The chair of the Chamber of Deputies' EAC is also considering requesting government to regularly report not only on its mandate for European Council meetings, but also on the Council's outcomes. By the end of February 2018 this had, however, not been mentioned or proposed in any official document (Interview with Ondřej Benešík, Chair of the Committee for EU Affairs, Chamber of Deputies of the Parliament of the Czech Republic, 16/1/2018).

The German Bundestag is very influential. While it has no formal mandating powers, its positions are semi-binding: the exit of a member state falls under Art. 23 of the German constitution as described in the following: § 8 EUZBBG determines that the government, before participating in the negotiations on Art. 50, must give the Bundestag the opportunity to issue a statement. If the Bundestag does issue a statement, the government must take this as a basis for the negotiations ( $§ 8$ Abs. 2 EUZBBG). The German constitution (article 23) states that the Bundestag and the Bundesrat participate in European affairs. To this end, the German government must inform both extensively and as early as possible. The right for information includes the opinion formation within the government as well as the preparation and the proceedings of negotiations within the institutions of the EU (§ 3 Abs. 2 S. 1 EUZBBG; EUZBLG §3). The 'regulation about the cooperation of federal government and Bundestag in European affairs (EUZBBG, July 2013)' adds that the government must inform the Bundestag continuously and generally in written form. The German government is moreover obliged to inform the Bundesrat about undertakings in the scope of the EU, if these concern the interests of the Bundesländer (EUZBLG §2). In other words, the government must send explanatory memoranda outlining its position to the Bundestag on all EU proposals, and to the Bundesrat on all those potentially concerning the interests of the Bundesländer. It briefs the Bundestag and Bundesrat before taking a position in the Council and reports to both about the positions taken.

Article 45 determines that the Bundestag must summon the EAC, making it one of only a few committees mentioned explicitly in the constitution. The EAC is the central place for debates on European politics in the Bundestag. It has interdisciplinary responsibilities, set up as an integrated and 
cross-sectoral committee. ${ }^{1}$ In the case of Brexit, the issue was also raised in other committees, such as the economic committee, but the EAC was the most important venue for discussing Brexit (Interview with CDU 27/04/2018; interview with SPD 19/04/2018, interview with Die LINKE 13/04/2018). The EAC of the Bundesrat consults all EU Council and Commission proposals, esp. for regulations and guidelines, as well as white and green papers that are concerning the interests of the Bundesländer and performs subsidiarity checks. ${ }^{2}$ In addition, every committee has the power to summon a member of the government to provide written or oral statements (COSAC 2017).

In addition, European issues in the Bundestag are supported by a special 'Europe department' in the administration, with one staff dedicated exclusively to the EAC. It also created a horizontal informal working group including all the departments divisions in response to Brexit helping to formulate the future relationship in more detail, for example concerning research, politics, migration and defence.

It is to be expected that for the regulation of the future (trade) relations between the EU and the UK a new agreement will be passed, such as an association after Art. 217 AEUV or an agreement after Art. 218 AEUV (Lippert, van Ondorza 2016). Whether Art. 23 of the German constitution or Art. 59 Abs. 2 S. 1 German constitution or yet another regulation applies, has not been clarified yet. ${ }^{3}$ The last element, the adaptation of the founding treaties after the UK's exit, will require the participation of the Bundestag and Bundesrat according to Art. 23 of the German constitution. Regarding scrutiny, there is a crucial difference between the Luxembourgish parliament on the one hand and the Czech Republic and Germany on the other. Luxembourg has a unicameral parliament. Both the Czech Republic and Germany have bicameral parliaments, with the upper houses having an independent scrutiny impact and acting as their own actors at EU level. Our analysis shows that when differentiating between the scrutiny activities of the unicameral parliament and the upper (the Czech Senate and the German Bundesrat) and the lower houses (the Czech Chamber of Deputies and the German Bundestag), we get different results in terms of frequency and intensity of scrutiny around Brexitrelated issues.

These results confirm recent research showing that unicameral parliaments, upper and lower houses vary not only in terms of their institutional rights and their general level of activity, but also regarding

\footnotetext{
1 The Bundestag EAC, however, is not the only committee responsible for the scrutiny of EU proposals. All committees discuss European affairs within their respective specialized areas. But the EAC is interdisciplinary and deals with cross-cutting policy as well as issues relating to European integration in particular. It scrutinizes the government's position throughout the whole EU legislative process and on all proposals. More details on https://www.bundestag.de/ausschuesse/ausschuesse18/a21/rechtsgrundlagen (accessed 20/02/2018).

2 See https://www.bundesrat.de/DE/bundesrat/ausschuesse/eu/eu.html?nn=4353202 (accessed 20/02/2018).

3 See https://www.bundestag.de/blob/484626/a4135f26572436921ebcd0baa150a63b/wd-3-224-16-pdfdata.pdf (accessed 20/02/2018).
} 
their kind of activity (Auel, Rozenberg and Tacea 2015). Unicameral parliaments, according to Auel, Rozenberg and Tacea, "are clearly the most active when it comes to issuing mandates or resolutions, but they debate EU affairs far less often in the plenary than chambers in bicameral parliaments" (Auel, Rozenberg and Tacea 2015:75). We cannot confirm this for the Luxembourg parliament in the case of Brexit. Attempts to actively control the government through resolutions were very rare. Instead, Brexit was debated in the plenary as well as in the EAC, although starting only at a later stage in comparison to the Czech Republic, namely in 2016. Six parliamentary questions were asked in 2016 and 2017; one by the Déi Lénk on whether the Luxembourgish government would try to negotiate bilateral deals, and five by the CSV on the legality of the special deal that the EU had negotiated with the UK in February 2016, how many British citizens had applied for Luxembourgish citizenship, how to deal with highly skilled migrants from Britain after Brexit, whether there the government had commissioned impact assessments on Brexit, and whether the government had a strategy in the event of a hard Brexit. The Luxembourg parliament can therefore be categorized as Brexit scrutinizer and as an arena where an active Brexit debate is motivated.

As mentioned above, both German and Czech chambers rank high with regards to institutional strength (Auel, Rozenberg and Tacea 2015), which strongly correlates with a high level of activity. Taking Auel, Rozenberg and Tacea's findings as a basis, we would expect the German Bundestag to be extremely active in debating Brexit in the EAC, and at the same time also very actively debating Brexit in its plenary. Whilst we only have access to plenary protocols and not to EAC protocols, we do know that the Bundestag treats Brexit as a highly political topic. Brexit was debated oftentimes in the plenary and was frequently subject of debate in the EAC: 14 out of 55 meetings in the period between June 2015 until December 2017 had Brexit on the agenda (Interview with CDU 27/04/2018; interview with SPD 19/04/2018, interview with Die LINKE 13/04/2018; COSAC 2017). All parliamentary groups have set up internal structures to be able to follow the process through extensively. This is similar for the way Brexit is treated politically in the EAC. The parliamentary groups each have a member in the EAC dedicated specifically to 'Brexit' and Great Britain, who take the lead on the debate for their parliamentary group. The Bundestag EAC is also regularly receiving visits from Michel Barnier and other members of the European Commission's Article 50 Task Force. In addition to the weekly EAC meetings, a weekly one-hour-meeting of correspondents, where experts, the ministry of foreign affairs, and chief negotiators from the German government and the Commission took part, was set up in response to Brexit. These meetings have not been reinstated since the elections in autumn 2017, but according to one interviewee this is likely to be taken up again (interview with the Bundestag administration 19/04/2018). Also, the individual party factions set up internal working groups in response to Brexit (Interview with CDU 27/04/2018; interview with SPD 19/04/2018, interview with Die LINKE 
13/04/2018). This confirms the Bundestag as active Brexit scrutinizer and as an arena for active Brexit debate, whilst resolutions and mandates were less important parliamentary tools for Brexit in the Bundestag.

The Czech Chamber of Deputies, on the other hand, would be expected to be a 'Brexit scrutiny laggard', with a very low overall level of activity, according to Auel, Rozenberg and Tacea's results. This is, however, not the case. The Czech Chamber of Deputies discussed Brexit in 26 percent of its EAC minutes in the period from 27/11/2013 until 26/10/2017. Whilst Brexit was debated to a lesser extent and more broadly in the plenary, debates regularly took place in context with statements given by the government prior to European Council meetings. A motion for a resolution was agreed within the EAC, but did not get approved in the plenary in time before the electoral campaign. The Czech Chamber of Deputies can thus be concluded to be an active Brexit scrutinizer, however, without actual attempts to influence the government or the European Commission.

The literature would expect the Bundesrat to foremost make use of mandates and resolutions as Brexit scrutiny tools on EU affairs. In the case of Brexit, the Bundesrat made use of its plenary to debate the topic in far less instances than the Bundestag (mentioned in six plenaries, two of which had Brexit on the agenda). We lack information on the use of the Bundesrat EAC for debating Brexit. The Bundesrat did, however, pass a resolution demanding the government keep the Bundesrat informed closely and appropriately (according to Art. 23) during the negotiations of the UK's exit and the regulation of a new partnership. It moreover requested for two members of the Bundesrat to participate in the EU Councils working group on Brexit (according to EUZBLG §6). This confirms the Bundesrat as 'policy shaper', attempting to influence the government's Brexit negotiating position through resolution(s).

The Czech Senate would be expected to be extraordinarily active in debating Brexit in the plenary. We found this to be true, with Brexit discussed in ranging between $50 \%$ of its EAC minutes in the period from $21 / 11 / 2014$ until $18 / 10 / 2016$ and $81 \%$ in the period from 16/11/2016 until 31/12/2017. Additionally, we find the Czech Senate to be very actively debating Brexit in the plenary, covering a range of Brexit-related issues. The Czech Senate moreover adopted three resolutions, one requesting that government to keep the Senate informed about the negotiations progress and to "consult Senate regarding the future relation between EU and United Kingdom as well as the future relation between the Czech Republic and the United Kingdom" (Senate Minutes 14/7/2016). The other two resolutions interpreted the British departure from the EU in a broader context: a resolution on the White paper on the future of the EU (Senate of the Parliament of the Czech Republic Resolution No. 232) and a resolution on the future of the EU (Senate of the Parliament of the Czech Republic Resolution No. 138). 
The Czech Senate is thus a very active Brexit scrutinizer as well as an active 'policy shaper', attempting to influence the government's Brexit negotiating position through resolutions.

In summary, we find the different parliaments, unicameral, and the upper and lower houses in the bicameral parliaments, to vary in their approach to Brexit scrutiny or rather their interpretation of their role vis-à-vis the government on Brexit-related issues. However, all chambers were found - to varying degrees - to be active in their chosen roles: Whether as active scrutinizers and arena for active debate (Czech Senate, Bundestag, Czech Chamber of Deputies, Luxembourg parliament) or as policy shapers (Czech Senate, Bundesrat).

\section{Procedural dimension}

In this section, we will analyse for what purpose the three parliaments used their procedures, whether they tried to extend them, and the role played by channels of interparliamentary cooperation.

Firstly, in terms of how parliaments make use of available procedures, our documentary analysis and interviews showed that parliamentary scrutiny of Brexit until late 2017 was a) largely reactive, b) that parliaments nevertheless tried to improve existing procedures, but c) mostly focused on information gathering rather than influence in practice. The fact that the first stage of Brexit negotiations revolved around issues on which the EU-27 could generally agree undoubtedly contributed to this. Thus, all three governments supported the common EU position, and all three parliaments supported their governments, which meant that all three parliaments had broadly similar positions. All three wanted to prevent 'cherry-picking' on the part of the UK, insisted that the single market goes hand in hand with the four freedoms and that the questions of the rights of EU and British migrants after Brexit has to be resolved. Moreover, all four expected the Northern Ireland question to be resolved and the UK to pay its financial obligations. In addition, there are a few country-specific concerns, such as the German contribution to the EU budget or the future of the financial place in Luxembourg.

Overall, we found that the timing of parliamentary activities in all cases followed a similar path and direction: all chambers were rather reactive than active, i.e. their Brexit activities were shaped by external events, be it the British referendum or subsequent European Council meetings. Whereas we can hardly find any substantial interest in UK issues prior to June $2016^{4}$, the referendum and its result triggered plenary debates in all cases. Secondly, all chambers were in this sense reactive to actions by their government, locked in their institutional possibilities and traditions. In the Czech case, for

\footnotetext{
${ }^{4}$ For example, the Czech parliament started to follow the issue prior to the 2015 June European Council meeting (Chamber of Deputies, European Affairs Committee Minutes 24/06/2015, Senate of of the Parliament of the Czech Republic European Affairs Committee Minutes 13/6/2015). During this period, however, the agenda of the British future in the EU was heavily overshadowed by the migration crisis. The same applies to Luxembourgish parliament, which started to become more active since 2015, showing no interest in 2013 or 2014.
} 
example, Brexit was discussed particularly in the context of governmental mandates for European Council meetings (and in the case of the Senate also debriefings on their outcomes). In the Luxembourgish case, scrutiny also largely revolves around committee or plenary debates with ministers. ${ }^{5}$ Unique was, however, the weekly hour to report on Brexit, which the German parliament had institutionalised during the previous government (see section above), in addition to plenary and committee debates in response to external events.

However, we can see differences in how the parliaments de facto positioned themselves on the procedural level. All three parliaments improved their scrutiny procedures for the Brexit negotiations. The Luxembourgish and Czech parliaments focused on information gathering, whereas the German parliament tried to improve its channels for influence.

In the Luxembourgish case, the parliament adopted a resolution in July 2017 asking the ministers to attend committee meetings after every session of EU negotiation on Brexit (4/07/2017). However, both the German and Czech parliaments pushed more actively for special procedures on Brexit and/or had more extensive formal powers to begin with. In the Czech case, the EAC can mandate the government before Council meetings (unlike the Luxembourgish EAC). In addition, on 27th of June a special Working group for Brexit and the future of the EU was established under the supervision of the Office of Government. In the beginning of its existence, the composition of the group was criticized by the opposition, particularly in the Chamber of Deputies EAC (Chamber of Deputies, European Affairs Committee Minutes 15/9/2016). Apart from this group, a political group consisting of representatives of major political parties was established. This group also involved MPs and its activity resulted in a deal on Czech priorities for Brexit negotiations signed in February 2017, as mentioned in the previous section.

In the German case, all parties in both chambers demanded to be informed continuously and thoroughly about the Brexit negotiations. The Bundestag wished to be in direct contact with the negotiating team as well as other parliaments and the European Commission, being given the opportunity to ask questions and obtain further clarifications on the progress of the negotiations (COSAC 2017). The Bundesrat took a proactive step to assure its involvement: On 31 March 2017 the Bundesrat passed a resolution clarifying that it expects the government to keep the Bundesrat informed closely and appropriately (according to Art. 23) during the negotiations of the UK's exit and the regulation of a new partnership. In addition, it asked to participate in the deliberations of the government's position already before negotiations were taken up, as well as during negotiations, and

\footnotetext{
${ }^{5}$ There were three plenary debates in Luxembourg on Brexit between 2015 - 2017. Moreover, on 21 March 2017 Foreign Minister Jean Asselborn briefed the Chambre on the key issues of the first stage of the negotiations.
} 
demanded two members of the Bundesrat to be allowed to participate in the EU Councils working group on Brexit (according to EUZBLG §6). It moreover expects to be included in the legislative measures for the adaptation to Brexit at the national level at an early stage. In response, the minister of state Michael Roth judged in agreement with the government that the Bundesländer are "generally not concerned" (member of the Bundesrat, plenary protocol 31 March 2017) during the negotiations of the European Council in the first phase of setting up guidelines for negotiation. This caused great discontent amongst members of the Bundesrat at the plenary (protocol 31 March 2017). In response to the initial request, the German foreign ministry set up an informal working group on Brexit for the government and the Bundesländer after the European summit in the summer 2017. It did not, however, invite members of the Bundesrat to attend meetings of the EU Council.

Finally, parliamentary activities related to Brexit also took place at international level. Members of the negotiating team reported to the parliamentary representatives in Brussels during Monday Morning Meetings on two occasions - after the notification of Brexit and in December 2017 (Interview with the NPR of the Bundesrat, 25/04/2018; Interview with the NPR of the Czech CoD; 2/05/2018). In addition, the head of the negotiating team, Michel Barnier, addressed a COSAC meeting in May 2017, and Commission Vice-President Frans Timmermans addressed a meeting of the COSAC chairpersons in January 2018. At these meetings, representatives of the European Affairs Committees of all member state parliaments (and some observer parliaments) are gathered. However, these meetings present opportunities mainly for the exchange of views among parliaments (and occasionally negotiators) and for the collection of first-hand information. None of the interviewees from Germany, Luxembourg or the Czech Republic felt that the goal was to reach a joint parliamentary position, or even that parliaments were actively trying to find a common position (ibid.; Interview with a member of the COSAC secretariat, 26/04/2018; Interview with the NPR of Luxembourg, 25/04/2018; Interview with the NPR of the Czech Chamber of Deputies, 2/05/2018). There are two reasons for this: firstly, the negotiations themselves are still rather vague and it is far from clear what the general direction of the outcome will be, which means that there is no incentive/opportunity for parliaments to discuss concrete goals. For example, while both Czech EACs are active at the international level, and particularly in COSAC, they found that Brexit was being discussed as a rather abstract issue (Interview with Václav Hampl, Chair of the Committee for EU Affairs, Senate of of the Parliament of the Czech Republic 23/1/2018, Interview with Ondřej Benešík, Chair of the Committee for EU Affairs, Chamber of Deputies of the Parliament of the Czech Republic 16/1/2018). It was thus overshadowed by more concrete and pressing issues like the migration crisis (Interview with Ondřej Benešík, Chair of the Committee for EU Affairs, Chamber of Deputies of the Parliament of the Czech Republic 16/1/2018) or - in the case of the NPRs - ongoing legislative processes, which are their main task. 
Secondly, the interests of national parliaments are not uniform with regard to concrete issues. For example, the BENELUX countries traditionally cooperate closely, and also do so on Brexit. Their foreign ministers met every month in 2018 to discuss this topic. However, while discussions are often extremely technical and precise (e.g. on the precise consequences of a hard Brexit on the financial sector and existing contracts), the attempts to find a common position are limited. On the one hand, Belgium is less interested in the financial sector than Luxembourg and the Netherlands, and Luxembourg is less interested in trade in goods, the customs union etc. than the other two, as it has no big ports from which large quantities of goods are shipped from and to the UK. In addition, even where interests overlap, e.g. in the banking sectors, countries are not just allies but also competitors, which means that they have an interest in keeping their cards close to their chest (Interview with staff of the Luxembourgish Parliament, 24/04/2018).

This has played out differently in the case of the Visegrad Four group. Its meetings were used as a space for mutual coordination, particularly if the Visegrad Four meeting preceded a COSAC conference (Interview with two employees of the Parliamentary Institute 10/1/2018). The Visegrad Four EAC's share goals and priorities regarding Brexit, and there is a good interpersonal relationship between its members. This is creating an excellent space for regular and intensive communication and exchange of views on Brexit (Interview with Ondřej Benešík, Chair of the Committee for EU Affairs, Chamber of Deputies of the Parliament of the Czech Republic 16/1/2018). Brexit holds similar implications ${ }^{6}$ for the Visegrad Four countries' citizens and their EACs moreover feel that they are going to lose an important ally in EU politics (Interview with Ondřej Benešík, Chair of the Committee for EU Affairs, Chamber of Deputies of the Parliament of the Czech Republic 16/1/2018, Interview with one employee, EU Affairs Department, Office of the Senate of the Parliament of the Czech Republic 10/1/2018), particularly those that are not members of the Eurozone (Interview with Ondřej Benešík, Chair of the Committee for EU Affairs, Chamber of Deputies of the Parliament of the Czech Republic 16/1/2018).

Finally, national parliaments also cooperate bilaterally or in smaller groups. The German parliament has exchanges with the British parliament, and the BENELUX also meet with the British parliament (Interview with staff of the Luxembourgish Parliament, 24/04/2018). In addition, do the parliamentary documents show that some bilateral committee meetings of EU-27 parliaments have taken place, and that Michel Barnier and other members of the negotiating team have visited national parliaments.

\footnotetext{
${ }^{6}$ A large number of these countries' citizens are working and living in the United Kingdom. For example, in 2016, the largest population of non-British UK residents was Polish people.
} 


\section{National interest vs party politics}

Party politics have become, particularly in the recent years, a more important factor of EU politics. This goes hand in hand with the increased politicization of the integration process, but also with multiple crisis the EU has been facing. In this sense, we expected that the negotiation process could intensify government-opposition tensions at parliamentary level and might trigger a different reaction by Eurosceptic parties, who might be more sympathetic towards the goal of leaving the EU.

However, this did not prove to be true. Brexit was not an issue affecting government-opposition dynamics. Even the Czech Eurosceptics did not use it as a platform. This is probably hardly surprising in the Luxembourgish and German cases, where the EU agenda does not represent a controversial issue, but it is surprising in the Czech case, where EU issues have polarized political discussion for many years.

The non-controversial profile of Brexit can be explained particularly by traditional consensual EU debates and well-established processes of formulating EU policy. This is true especially for Luxembourg. Luxembourg's population is relatively pro-European in general, and thus the parties are also pro-European in general. All three government parties (the Social democrats (LSAP), Liberals (DP), Greens (dei Gren)), and the biggest opposition party (the Christian Democrats (CSV)) are pro-European. Even the two minor opposition parties - left wing dei Lenk and right-wing ADR - cannot be considered as Eurosceptical, but rather as Eurocritical, i.e. they are in favour of EU integration, but would like the EU to be more social or to leave more room for the member states. In addition, the next national elections are in autumn 2018, and none of the parties' views Brexit as a theme that could mobilize voters (Interviews with an ADR MP, 13.02.18; an LSAP MP, 14.02.18; a CSV MP, 13.04.18; a dei Lenk $M P, 13.04 .18)$. As a result, both parliamentary documents and interviews confirm that the three governmental parties and the CSV have largely identical positions on Brexit (Interview with an LSAP MP, 14.02.18; interview with a CSV MP, 13.04.18; interview with an dei Lenk MP, 13.04.18).

Similarly, in Germany, the coalition parties (until 2017 CDU and SPD) as well as the opposition party Bündnis90/Die Grünen (Greens) stand behind the general line of a unified approach of the EU27 and do not wish to enter bilateral negotiations or start their own plans with other national parliaments. The other opposition party, die LINKE (Leftist party), agrees with the contents of the EU approach, but not with the process or rather the handling of the negotiations. Since the new government was formed in March 2018, two parties joined the opposition: the centre-right liberal democratic party FDP and the right wing Alternative für Deutschland AfD. The former is generally pro-European. The AfD is mildly supportive of Germany's EU membership - although the party is divided on this issue - but is clearly 
sceptic towards the EU in terms of further integration, immigration, the euro, and bailouts for the eurozone. It interpreted Brexit as a confirmation of its own ideology. ${ }^{7}$

Probably the most interesting case represents the Czech Republic. Compared to both Germany and Luxembourg, the Czech EU discussion has been highly polarized and the Czech political party scene has always been characterized by the presence of strong Eurosceptic parties, traditionally in the form of the conservative Civic Democrats (ODS) and the Communists (KSČM). Apart from these two "usual suspects", a far right and Eurosceptic party called Freedom of Direct Democracy (SPD) entered the scene after the October 2017 elections. Despite all this, there was broad political consensus in the Czech parliament regarding the national priorities for Brexit as well as the way in which these should be achieved. Formal agreement among major political parties was reached and signed in February 2017. An initiative for this agreement came out from the opposition - more specifically, it was ODS which brought it on the table - which made it more acceptable. The Senate's EAC chair also participated in its drafting (Interview 1, Interview 4). Moreover, the fact that the Czech position was much in line with the EU approach helped to avoid potential controversy around the issue. Insiders involved in the process expected that this would not change unless there either was substantial reformulation of the Czech EU governmental policy or future Czech and EU priorities drifted apart (Interview 3). Despite the absence of political controversy, a number of politicians (and especially the EAC chairs) were very active and felt that Brexit was an issue where a lot was at stake for their country (Interviews 3 and 4).

The general lack of controversy does not mean that differences - particularly in terms of dissent voices on specific issues - do not exist. In the German case, Die LINKE felt that the Northern Irish question could not be settled in the first phase of negotiations. In addition, in terms of citizen's rights, all German parties agreed that the rights should not be diminished and that this a central issue, however, the SPD for example believed this could only be settled at the end of the negotiations, whilst Die LINKE thought that the rights should have been cast in stone beforehand, to reduce uncertainties for the citizens concerned (Interview with SPD 19/04/2018, interview with Die LINKE 13/04/2018). Die LINKE was furthermore against putting pressure on completing the negotiations within two years and rather wanted to prolong that period. There were also some nuances in language and rhetoric used - for example, SPD and Greens adopted rather a harder line against the UK and more frequently use rhetoric punishing the UK for the decision to exit than the CDU or Die LINKE (Interview with SPD 19/04/2018, interview with Die LINKE 13/04/2018).

\footnotetext{
${ }^{7}$ See for example http://www.handelsblatt.com/politik/international/brexit-referendum/brexitnews/alternative-fuer-deutschland-brexit-chaos-in-der-afd/13792100.html (accessed May 2018).
} 
Similar small hints could be found also in case of Luxembourg. Here, the ADR is somewhat more understanding of the British decision to leave the EU, as it is a sister party of the British Conservatives. It agrees with them that the EU should return some competences to the member states, but it does believe that Luxembourg should remain a EU member state. However, when it comes to the national interests to be defended in the negotiations, its position resembled that of the other four parties (Interview with an ADR MP, 13.02.18). Dei Lenk was the only party that was positioning itself differently in term of contents: for example, it perceived Brexit as a result of the weak social dimension of the EU, and it criticized the focus of the government on the financial sector (Interview with a dei Lenk MP, 13.04.18).

Finally, we would have expected the national parliaments to discuss different issues, depending on which issues are the most salient for the respective countries. In fact, the parliaments discussed a similar range of issues, but there were differences in how much emphases were placed on specific issues.

During the first phase of negotiations, the three issues discussed between the EU and the UK were citizen's rights, the Northern Ireland border and the financial settlement. These issues were also taken up in the broader debates within the parliaments of the Czech Republic, Germany and Luxembourg. This first phase of the negotiations was moreover characterized by an overwhelming unity of the EU27, represented through Michel Barnier in the negotiations with the UK. The parliaments of the three countries backed this approach and are clear on 'no cherry-picking' as well as the non-negotiability of the four freedoms and the single market.

However, beyond these topics, we observe that the three parliaments focused on issues of national salience. Luxembourg is home to a prominent financial sector and thus the impact of Brexit on the latter has become the most salient issue in Luxembourg. Germany, the country with the biggest economic weight in the EU, is concerned about an aversion amongst the public to paying a larger share of the EU budget after the leave of the UK. Without any reforms, Germany's share in the EU budget will rise considerably. The CDU in the Bundestag, part of the coalition government, is supporting a proposed reform of the EU budgetary system in view of Brexit. The oppositional Green party, on the other hand, suggested to increase Germany's share of the budget by $8 \%$, which they believe would fill the gap created by the UK's exit and also Die LINKE is prepared to pay a larger part (Interview with Die LINKE 13/04/2018). The Bundesrat, too, is focussing its scrutiny on the EU budget, because with the UK leaving the EU, Germany becomes - statistically - economically stronger and the new Bundesländer lose the right to EU financial support. In the Czech Republic, both, the Chamber of Deputies as well as the Senate focused on the generally salient issues of citizens' rights and the financial settlement. 


\section{Conclusion}

National parliaments' involvement in EU politics has increased in recent years. Their current activities in the Brexit process confirm this development. Indeed, the national parliaments analysed are surprisingly active given the low activity scores of some in Auel et al. (2015). So far, their interest in national as well as international level developments has been continuous and driven by events and actions taking place outside domestic constituencies, in particular, European Council meetings and milestones in the negotiation process.

To what extent does Brexit represent a unique opportunity for national parliaments to further increase their power in the EU policies of their states? Based upon existing literature, we expected their behaviour in the Brexit process to follow already established patterns - institutional strength and capacity playing a role as well as a focus on key national priorities. We also expected unicameral systems to pursue different scrutiny activities to bicameral systems.

Our findings confirm our initial assumptions only partly. The constitutional dimension was probably closest to the bull's eye - as expected, we found the different parliaments, unicameral, and the upper and lower houses in the bicameral parliaments, to vary in their approach to Brexit scrutiny or rather their interpretation of their role vis-à-vis the government on Brexit-related issues. However, all chambers were found to be active in their chosen roles: Whether as active scrutinizers and arena for active debate (Czech Senate, Bundestag, Czech Chamber of Deputies, Luxembourg parliament) or as policy shapers (Czech Senate, Bundesrat).

Regarding the procedural level, we did not find remarkable differences among chambers in terms of their involvement and activity, as assumed. Parliaments have in general followed similar patterns of behaviour, focusing particularly on information gathering and government monitoring. Even though some chambers have adjusted their scrutiny mechanisms, the vast majority of their activities have been taken up in already established procedures and frameworks (except for the Bundestag, which set up a weekly Brexit correspondence). Moreover, parliaments have not tried to challenge governmental primacy in Brexit negotiations so far (except for the Bundesrat), thus adopting a reactive approach. Thus, neither our three case study parliaments, nor the Irish, Spanish, Belgian or Polish parliaments studied in other chapters have used Brexit as an opportunity to extend their powers vis-à-vis government (Bar Cendón 2019; Barrett 2019; Boronska-Hryniewiecka 2019; Brack and Sierens 2019). Although chambers talked about different issues and put a different emphasis on issues - partly dependent on nationally salient topics - all of them have covered and agreed on the EU's Brexit priorities such as citizens' rights' protection, the Northern Ireland question, and the financial settlement between the UK and the EU. 
Most surprisingly, the party politics expectation was not confirmed at all. The first stage of negotiations did not increase government-opposition tension, neither was it exploited differently by Eurosceptics and by pro EU parties. This finding holds for all three countries, including the Czech Republic, where the EU agenda generally is a very controversial topic. We identified some voices of dissent - particularly in Germany - but these addressed mainly procedural or smaller issues and did not disagree with the content of the general consensus on Brexit. Interestingly, this finding is also largely repeated across the other chapters looking at national parliaments and Brexit (Bar Cendón 2019; Barrett 2019; Boronska-Hryniewiecka 2019; Brack and Sierens 2019): The authors analysing the Irish, Spanish and Belgian parliaments also found that there was no government-opposition divide on the substance of Brexit and that all parties rallied around a joint vision of national interest. In Poland, Brexit led to disagreements between Eurosceptic and pro-European parties. However, as in the Luxembourgish case, these disagreements appear to focus on the interpretation of the causes of Brexit rather than desirable outcomes, with some Luxembourgish and Polish MPs expressing 'understanding' for the decision to leave the EU. This- in their view - was grounded in the EU's shortcomings.

Our findings should be considered in context, which explains why some assumptions were met and some were not. Firstly, even though Brexit touches upon several important issues, it did not headline the daily political agenda of the analysed countries. The low political salience of the Brexit negotiations was further strengthened by the fact that there was wide consensus on national priorities among relevant political forces in the EU, as well as broad support for the existing EU approach. In the period analysed, the talks between the EU and the UK touched mainly general topics and issues where consensus - at least on the EU side - could easily be reached. Therefore, Brexit - or at least the first phase of its negotiations - failed to trigger party political competition.

The question is, if this development continues into the later stages of the Brexit talks. Our prediction is that it probably will and that the Brexit parliamentary game in the countries analysed is also likely to follow a consensual pattern in the future. So far, the main sources of disagreement are issues related to the future of the EU-27 after Brexit (e.g. the multiannual financial framework), but those discussions are not directly related to the Brexit negotiations. This could of course change when more detailed and specific issues are discussed and when national governments may try to promote - or block - special deals with the UK in concrete sectors and policy areas. Here the question is whether potential controversies could be utilized by national parliaments - but considering the highly technical nature of such discussions, substantial change is unlikely. This prediction was supported by some of our interviewees - for example, German MPs interviewed (Interview with CDU 27/04/2018; interview with SPD 19/04/2018) did not expect the support for a united EU approach to flag. Even though some 
chambers demanded special procedures for Brexit scrutiny - the German Bundestag and Czech Senate - actual parliamentary activity requires other sources of motivation.

\section{Bibliography}

Auel, Katrin, 'Introduction: The Europeanization of Parliamentary Democracy', Journal of Legislative Studies 11, no. 3-4 (2005): 303-318.

Auel, Katrin and Thomas Christiansen, 'After Lisbon: National Parliaments in the European Union', West European Politics 38, no. 2 (2015): 261-281.

Auel, Katrin and Höing, Oliver, 'National Parliaments and the Eurozone Crisis: Taking Ownership in Difficult Times?', West European Politics 38, no. 2 (2015): 375-395.

Auel, Katrin, Rozenberg Oliver and Angela Tacea (2015), 'Fighting Back? And, If So, How? Measuring Parliamentary Strength and Activity in EU Affairs', in The Palgrave Handbook of National Parliaments and the European Union, Ed. Claudia Hefftler, Christine Neuhold, Olivier Rozenberg, and Julie Smith (New York: Palgrave Macmillan, 2015), 60-93.

Bar Cendon, Antonio, 'The Spanish Parliament and Brexit', in: (2019).

Barrett, Gavin, 'The Irish Parliament and Brexit', in: (2019).

Brack, Natalie, Sierens, Vivien, 'Brexit as a divisive issue. Studying the role and action of parliaments in Belgium', in: (2019).

Bergman, Torbjörn, Wolfwang C. Müller, Kaare Strøm, and Magnus Blomgren (2003) 'Democratic delegation and accountability: cross-national patterns', in Delegation and Accountability in Parliamentary Democracies, Ed. Kaare Strøm, Wolfgang C. Müller, and T. Bergman (Oxford: Oxford University Press, 2003), 109-220.

Boronska-Hryniewiecka, Karolina (2019), 'The Polish Parliament and the Scrutiny of Brexit in Poland', in: (2019)

Chamber of Deputies of the Parliament of the Czech Republic Minutes 30/6/2016.

Chamber of Deputies of the Parliament of the Czech Republic Minutes 12/4/2017.

Chamber of Deputies of the Parliament of the Czech Republic European Affairs Committee Minutes $24 / 06 / 2015$. 
Chamber of Deputies of the Parliament of the Czech Republic European Affairs Committee Minutes $14 / 10 / 2015$.

Chamber of Deputies of the Parliament of the Czech Republic European Affairs Committee Minutes $17 / 12 / 2015$

Chamber of Deputies of the Parliament of the Czech Republic European Affairs Committee Minutes $17 / 2 / 2016$

Chamber of Deputies of the Parliament of the Czech Republic European Affairs Committee Minutes $15 / 9 / 2016$

COSAC (2017), Twenty-seventh Bi-annual Report: Developments in European Union Procedures and Practices Relevant to Parliamentary Scrutiny, 3. May 2017.

Dimitrakopoulos, Dionyssis G., 'Incrementalism and Path Dependence: European Integration and Institutional Change in National Parliaments', Journal of Common Market Studies 39, no. 3 (2001): 40522.

Eleftheriadis Pavlos, 'Constitutional Illegitimacy over Brexit', The Political Quarterly 88, no. 2 (2017): $182-188$

Gattermann Katjana, Anna-Lena Högenauer, and Ariella Huff, 'Research note: studying a new phase of europeanisation of national parliaments', European Political Science 15, no. 1 (2016): 89-107.

Gee Graham and Alison L. Young, 'Regaining sovereignty? Brexit, the UK Parliament and the common law', European Public Law 22, no. 1 (2016): 131-147.

Högenauer Anna-Lena, Christine Neuhold, and Thomas Christiansen (2016), Parliamentary Administrations in the European Union (London: Palgrave).

Högenauer, Anna-Lena and Christine Neuhold, 'National Parliaments after Lisbon: Administrations on the Rise?', West European Politics 38, no. 2 (2015): 335-354.

Hrabálek, Martin, and Alexander Strelkov, 'The Czech Parliament and European Integration', in The Palgrave Handbook of National Parliaments and the European Union, Ed. Claudia Hefftler, Christine Neuhold, Olivier Rozenberg, and Julie Smith (New York: Palgrave Macmillan, 2015), 494-513.

Interview with Václav Hampl, Chair of the Committe for EU Affairs, Senate of the Parliament of the Czech Republic, 23/1/2018 
Interview with Ondřej Benešík, Chair of the Committe for EU Affairs, Chamber of Deputies of the Parliament of the Czech Republic, 16/1/2018.

Interview with two employees of the Parliamentary Institute, 10/1/2018.

Interview with one employee, EU Affairs Department, Office of the Senate, 10/1/2018.

Lippert, Barbara, and Nicolai Von Ondarza (2016), Der Brexit als Neuland. SWP-Aktuell, 42, July 2016. Interview with CDU 27/04/2018: Interview with Detlef Seif, CDU MP responsible for the reporting on the UK, Ireland and the art. 50 of the treaty of the EU negotiations in the Bundestag EAC, 27 April 2018. Interview with SPD 19/04/2018: Interview with Axel Schäfer, SPD MP, responsible for the reporting on the UK and Brexit in the Bundestag EAC, 19 April 2018.

Interview with Die LINKE 13/04/2018: Interview with René Jokisch, Europe expert responsible for the EAC and Brexit for Die LINKE faction in the Bundestag, 13 April 2018.

Interview with the Bundestag administration 19/04/2018: Interview with Dr. Sven Vollrath, head of the Europe sub-department of the German Bundestag administration, 19 April 2018.

Mabbett, Deborah (2017), 'Parliamentary Sovereignty and Brexit', The Political Quarterly 88, no. 2 (2017): 167-69.

Maurer, Andreas, and Wolfgang Wessels (eds) (2001) National Parliaments on their Ways to Europe. Losers or Latecomers? (Baden-Baden: Nomos Verlag).

Norton, Philip (ed.) (1996) National parliaments and the European Union, London: Frank Cass.

O'Brennan, John and Tapio Raunio (2007) (eds) National Parliaments within the Enlarged European Union: From 'victims' of integration to competitive actors? (Abingdon: Routledge).

Phillipson Gavin, 'A Dive into Deep Constitutional Waters: Article 50, the Prerogative and Parliament', Modern Law Review 79, no. 6 (2016): 1064-1089.

Poole Thomas, 'Devotion to Legalism: on the Brexit Case', Modern Law Review 80, no. 4 (2017): 696710.

Resolution of Chamber of Deputies of the Parliament of the Czech Republic European Affairs Committee No. 394.

Senate of the Parliament of the Czech Republic Minutes 14/7/2016.

Senate of the Parliament of the Czech Republic Committee for EU Affairs Minutes 25/1/2016. 
Senate of the Parliament of the Czech Republic Committee for EU Affairs Minutes 15/5/2016.

Senate of the Parliament of the Czech Republic Committee for EU Affairs Minutes 17/2/2016.

Senate of the Parliament of the Czech Republic Resolution No. 138.

Winzen, Thomas, 'National Parliamentary Control of European Union Affairs: A Cross-national and Longitudinal Comparison', West European Politics 35, no.3 (2012): 657-672. 